\title{
Article \\ Production of a Yogurt Drink Enriched with Golden Berry (Physalis pubescens L.) Juice and Its Therapeutic Effect on Hepatitis in Rats
}

\author{
Magdy Ramadan Shahein ${ }^{1}$, El Sayed Hassan Atwaa ${ }^{2}$, Hanan A. Radwan ${ }^{3}$, Abdelmoneim Ahmed Elmeligy ${ }^{4}$, \\ Amin A. Hafiz ${ }^{5}$, Ashraf Albrakati ${ }^{6}$ (D) and Ehab Kotb Elmahallawy ${ }^{7} * \mathbb{D}$
}

\section{check for} updates

Citation: Shahein, M.R.; Atwaa, E.S.H.; Radwan, H.A.; Elmeligy, A.A.; Hafiz, A.A.; Albrakati, A.; Elmahallawy, E.K. Production of a Yogurt Drink Enriched with Golden Berry (Physalis pubescens L.) Juice and Its Therapeutic Effect on Hepatitis in Rats. Fermentation 2022, 8, 112. https://doi.org/10.3390/ fermentation 8030112

Academic Editor: Donatella Cimini

Received: 1 January 2022

Accepted: 4 March 2022

Published: 6 March 2022

Publisher's Note: MDPI stays neutral with regard to jurisdictional claims in published maps and institutional affiliations.

Copyright: (c) 2022 by the authors. Licensee MDPI, Basel, Switzerland. This article is an open access article distributed under the terms and conditions of the Creative Commons Attribution (CC BY) license (https:// creativecommons.org/licenses/by/ $4.0 /)$.
1 Department Food Science and Technology, Faculty of Agriculture, Tanta University, Tanta 31527, Egypt; magdrsh10@gmail.com

2 Food Science Department, Faculty of Agriculture, Zagazig University, Zagazig 44511, Egypt; elsayedhassanattwa@gmail.com

3 Department of Home Economics, Faculty of Specific Education, Zagazig University, Zagazig 44511, Egypt; drhananalsadeq81@gmail.com

4 Department of Pathology, Faculty of Veterinary Medicine, Suez Canal University, Ismailia 41522, Egypt; elmeligy52@yahoo.com

5 Department of Clinical Nutrition, Faculty of Applied Medical Sciences, Umm AlQura University, Makka Al-Mukarama 21961, Saudi Arabia; aahafiz@uqu.edu.sa

6 Department of Human Anatomy, College of Medicine, Taif University, P.O. Box 11099, Taif 21944, Saudi Arabia; a.albrakati@tu.edu.sa

7 Department of Zoonoses, Faculty of Veterinary Medicine, Sohag University, Madinet Nasser 82524, Egypt

* Correspondence: eehaa@unileon.es

Abstract: Fermented dairy products have been associated with multiple health benefits. The present study aimed to produce a functional yogurt drink fortified with golden berry juice and assess its therapeutic effect on hepatitis rats. Thirty male albino rats were randomly divided into two major groups. The first group included the control (-) animals (six rats) and was fed a standard diet, whereas the second group included 24 rats that were fed a standard diet and injected with carbon tetrachloride $\left(\mathrm{CCl}_{4}\right)$ for 2 weeks to trigger chronic damage of the liver (hepatitis); they were then divided into four groups (six rats/group): Group 2: hepatitis, fed on a standard diet as a positive control group; Group 3: received a basal diet with $5 \mathrm{~mL}$ of the yogurt drink; Group 4: received a basal diet with $5 \mathrm{~mL}$ of the yogurt drink fortified with $10 \%$ golden berry juice. Group 5: received a basal diet with $5 \mathrm{~mL}$ of the yogurt drink fortified with $20 \%$ golden berry juice. Various biological parameters were determined. Yogurt drink treatments were evaluated for their chemical, phytochemical, and sensory properties, as well as for their effects on hepatoprotective activity by determining various biochemical parameters. We found that the yogurt drinks containing golden berry juice exhibited no significant differences in fat, protein, and ash content compared with the control samples. Moreover, the yogurt drinks containing golden berry juice exhibited the highest content of total phenolic compounds, antioxidant activity, and organoleptic scores among all treatments. In addition, rats fed on a diet fortified with yogurt drinks containing golden berry juice for 8 weeks exhibited higher potential hepatoprotective effects compared with the liver injury control group. This improvement was partly observed in the group that received the yogurt drink containing golden berry juice. Therefore, we concluded that golden berry juice can be recommended as a natural additive in the manufacture of functional yogurt drinks, as it showed a potential hepatoprotective effect in rats with hepatitis.

Keywords: Physalis pubescens L.; yogurt drink; phytochemicals; liver function; hepatoprotective

\section{Introduction}

Liver diseases remain among the most serious health problems worldwide; however, prevention and treatment options are limited in this context [1]. It is well established that 
pathogenesis, oxidative stress, and inflammation are the causes of liver disease, and that blocking and retarding the chain reactions of the oxidation and inflammation processes is a promising therapeutic strategy for the prevention and treatment of liver diseases [2,3]. Among others, carbon tetrachloride $\left(\mathrm{CCl}_{4}\right)$ poisoning has been associated with the production of reactive oxygen species (ROS), including superoxide and hydroxyl radicals, which play an important role in the development of liver disease [4,5]. Trichloromethyl, which is a product of the primary metabolism of $\mathrm{CCl}_{4}$, is believed to initiate the biochemical processes that cause oxidative stress, which is the direct cause of many pathological conditions, such as cancer, hypertension, diabetes mellitus, kidney and liver damages, and even death $[5,6]$. Clinical and experimental evidence has largely demonstrated that oxidative stress is a major inducer of apoptosis in various types of acute and chronic liver injuries and in hepatic fibrosis [7]. Hepatic fibrosis induced by $\mathrm{CCl}_{4}$ is associated with the depletion of the antioxidant status and the exacerbation of lipid peroxidation $[5,8]$. Accordingly, the use of antioxidants and their interactions in the diet, which has attracted the attention of many researchers, presents a potential and effective therapeutic strategy for preventing or delaying the occurrence of hepatic fibrosis $[9,10]$.

The last few decades have witnessed a growing interest in the development of enriched dairy products for health-enhancing foods such as products fortified with fiber, low and non-fat products and functional foods [11,12]. It is noteworthy to state that dairy products are among the most important consumer preferences among functional foods since they are ideal products for fortification with functional ingredients, and therefore, these fortified dairy products have been extensively examined [13-16]. However, it should be taken into account that there is a growing trend to avoid dairy products due to some associated health problems such as lactose intolerance, cow's milk allergy and hypercholesterolemia $[17,18]$. Among others, yogurt is one of the most widely consumed dairy products due to its numerous health benefits [13-15,19]. The acceptance of consumers for functional fermented yogurt remains very high, particularly among older people and females of all ages, and they have expressed their willingness to incorporate such functional foods into their diet [12]. Numerous studies have indicated that natural substances from edible and medicinal plants have a strong antioxidant activity and can, thus, act against hepatotoxicity $[20,21]$. One of those candidate plants is Physalis peruviana L. or P. pubescens L., which is known locally in Egypt as harankash and in English-speaking countries as the golden berry. This fruit has many medicinal and edible uses [22], as it contains many active components, such as vitamins A, B, C, E and K, minerals, polyunsaturated fatty acids, carbohydrates, hydroxyester disaccharides, withanolides (steroidal lactones), carotenoids, phenolic acids (such as gallic, chlorogenic, ferulic, caffeic, and p-coumaric acids), flavonoids (such as myricetin, kaempferol, catechin, quercetin, and rutin), and epicatechin biologically active components that reduce the risk of certain diseases and provide health benefits (such as antiproliferative effects on hepatoma cells, anti-hepatotoxic effects, and anti-inflammatory activity) [23]. In addition, it has excellent potential as a food-based strategy to manage hypertension and diabetes [23-27].

The demand for yogurt drinks by consumers has increased because of their unique properties and their many health benefits. Yogurt drinks are rich in protein, B vitamins, calcium and potassium, which help to stabilize the immune system [28]. Several researchers studied the effect of some different additives on the properties of the resulting yogurt. The addition of stabilizers, such as xanthan and guar gum, and skim milk powder to non-fat yogurt showed a significant effect on sensory attributes [29]. In another study [30], the addition of $0.06 \mathrm{mg} / \mathrm{mL}$ of nanopowdered eggshell powder could be applicable to manufacture probiotic yogurt with an acceptable composition and quality as compared to the control. Furthermore, nanopowdered eggshell increased the shelf-life of probiotic yogurt, as compared to the control, with a range of $5 \mathrm{to} 7 \mathrm{log} \mathrm{cfu} / \mathrm{g}$ of probiotic yogurt. Likewise, the incorporation of zeaxanthin nanoparticles in yogurt allowed the dispersion of a hydrophobic compound in a hydrophilic matrix which provides more stability [31]. Another previous study [32] revealed that the addition of inulin in the manufacturing of 
probiotic yogurt as a prebiotic enhanced the growth of $\mathrm{Bb}$ and increased the shelf-life of the resultant yogurt. It is, therefore, not surprising to mention that the supplementation of yogurt with phenolic-rich products such as golden berry juice could be an ideal method for the optimization of the benefits of fermented dairy products with a high phenolic compound intake. Revising the available literature, several researchers demonstrated the potential benefits of the addition of fruit or vegetable juices in the preparation of functional fruit yogurt that included high acceptability, besides its role in the enhancement of the flavor, phenolic content and free radical scavenging activity of yogurt [11,33]. However, no previous research was performed on the addition of golden berry juice to yogurt, and therefore, it seems that the supplementation of yogurt with phenolic-rich products such as golden berry juice might optimize the benefits of fermented dairy products with a high phenolic compound intake. There is a need to clarify whether the addition of golden berry juice might change some specific aspects of fermented dairy products, such as fermentation time, growth of starter bacteria, acidification rate and the main physicochemical characteristics [11]. Given the above information, the present study aimed to investigate the impact of incorporating golden berry fruit juice in yogurt drink manufacturing and to fortify different proportions of yogurt drinks with their functional properties. Furthermore, the fortified yogurt drink was tested for its therapeutic effect as a functional food to treat artificially induced hepatitis in albino rats.

\section{Materials and Methods}

\subsection{Materials and Reagents}

Golden berry fruits were obtained from a local market (Zagazig, Egypt). Fresh cow standardized milk (3\% fat) was obtained from the Dairy Technology Unit, Food Science Department, Faculty of Agriculture, Zagazig University. Yogurt cultures containing Streptococcus salivarius subsp. thermophilus EMCC104 and Lactobacillus delbrueckii subsp. bulgaricus EMCC1102 were obtained from the Microbiological Resources Center, Faculty of Agriculture, Ain Shams University, Egypt. Moreover, 1,1-diphenyl-2-picrylhydrazyl (DPPH), gallic acid, $\mathrm{CCl}_{4}$, and Tris- $\mathrm{HCl}$ buffer were purchased from Sigma (St. Louis, MO, USA). All other chemicals and reagents used in this study were of analytical grade. Double-distilled water was used as the solvent. The basal pellet diets were obtained from the central animal house of the National Research Center, Dokki, Giza, Egypt. Water was provided ad libitum. The basal diet was prepared based on AIN 1993 [34]. Thirty-six male albino rats weighing between 150 and $200 \mathrm{~g}$ ( $\pm 10 \mathrm{~g}$ ) were obtained from the Agricultural Research Center, Giza, Egypt.

\subsection{Preparation of Golden Berry Fruit Juice}

The ripe golden berry fruits were de-husked manually, then washed. Subsequently, the fruits were pulped using a high-speed electric mixer, for juice extraction. The juice was filtered using cheesecloth to separate the seeds and skins and the fresh fruit juice was analyzed directly after production.

\subsection{Determination of Phytochemical Properties}

The total phenolic content (TPC) (mg GAE/100 g) and antioxidant activity (AO; \%) of the juice were assessed as described by Odabasoglu et al. [35] and Illupapalayam et al. [36], respectively, whereas the TPC and AO of the prepared yogurt drink were assessed as described by Maksimovic et al. [37] and Apostolidis et al. [38], respectively. Ascorbic acid (mg $100 \mathrm{~mL}^{-1}$ ) was assessed as described by Bajaj and Kaur [39]. The total carotenoid content $\left(\mu \mathrm{g} \mathrm{mL}^{-1}\right)$ was determined as described elsewhere [40].

\subsection{Yogurt Drink Manufacture}

Different treatments of yogurt drink were manufactured according to the procedure of [41], with some alterations as follows: Fresh Egyptian bulk cow's milk was separated to skim-milk and the resulting standardized cow's milk ( $3 \%$ fat) was heated at $85^{\circ} \mathrm{C}$ for 
$10 \mathrm{~min}$, then cooled to $42^{\circ} \mathrm{C} \pm 1{ }^{\circ} \mathrm{C}$ before adding the yogurt starter culture containing Streptococcus salivarius subsp. thermophilus and Lactobacillus delbrueckii subsp. bulgaricus (1:1) at a rate of $3 \%$, followed by incubation at $42^{\circ} \mathrm{C} \pm{ }^{\circ} \mathrm{C}$ and $\mathrm{pH}$ reached 4.65 until uniform coagulation was obtained. The developed yogurts were cooled overnight at $5{ }^{\circ} \mathrm{C} \pm 1{ }^{\circ} \mathrm{C}$. The yogurt drink treatments were carried out as follows:

- Control yogurt drink (C): plain yogurt was mixed with 50\% sterilized distilled water sweetened with $10 \%$ sugar (to achieve $5 \%$ sugar in the yogurt drink) at $25^{\circ} \mathrm{C}$.

- Yogurt drink fortified with 10\% golden berry juice (T1): yogurt was mixed with 30\% sterilized distilled water sweetened with $10 \%$ sugar and $20 \%$ pasteurized golden berry juice sweetened with 10\% sugar (to achieve 5\% sugar and 10\% golden berry juice in the yogurt drink).

- Yogurt drink fortified with 20\% golden berry juice (T2): yogurt was mixed with 10\% sterilized distilled water sweetened with $10 \%$ sugar and $40 \%$ pasteurized golden berry juice sweetened with 10\% sugar (to achieve $5 \%$ sugar and $20 \%$ golden berry juice in the yogurt drink). The drinking yogurt mixes were placed in 250-g plastic cups and then refrigerated until use in rat feeding. The samples were analyzed at day one.

\subsection{Methods of Analysis}

The total solids, fat, total protein, crude fiber, ash content, and titratable acidity of the yogurt samples were determined according to [40]. The changes in $\mathrm{pH}$ in the yogurt samples during storage were measured using a laboratory $\mathrm{pH}$ meter with a glass electrode (HANNA, Instrument, 4495-129 Amorim, Portugal).

\subsection{Sensory Evaluation}

A sensory evaluation of the yogurt drinks was carried out by a team of 10 professional panelists from the Faculty of Agriculture, Zagazig University, Egypt using the 5-point Hedonic Scale, according to Heymann and Lawless [42] The panelists were instructed to wash their mouths with low sodium spring water during the sensory evaluation session, and they were encouraged to write down any criticisms on the tested products. Plain and treated yogurt samples were presented in plastic cups coded with three-digit random codes. Each cup contained $100 \mathrm{~mL}$ of yogurt samples freshly removed from the refrigerator. The sensory evaluation was conducted using a comparative test with fresh yogurt as a reference sample. The data were collected in specially designed ballots.

\subsection{Experimental Design}

After acclimation on a basal diet for 7 days, 30 male albino rats weighing about $150 \pm 5 \mathrm{~g}$ were classified into two groups. The first $(n=6)$ was used as the normal control group and fed a standard diet. The second group of rats $(n=24)$ was injected twice per week with $\mathrm{CCl}_{4}$ in paraffin oil (50\% v/v $2 \mathrm{~mL} / \mathrm{kg}$ ) via subcutaneous injection (for 2 weeks), to induce chronic damage in the liver, as described elsewhere [43]. The rats with hepatitis were classified into four groups as follows. Group 2: hepatitis positive control group, fed a basal diet and water ad libitum; Group 3: received a basal diet of $5 \mathrm{~mL}$ of a yogurt drink via an epigastric tube for 8 weeks; Group 4: received a basal diet and $5 \mathrm{~mL}$ of a yogurt drink fortified with $10 \%$ golden berry juice via an epigastric tube for 8 weeks; and Group 5: received a basal diet and $5 \mathrm{~mL}$ of a yogurt drink fortified with $20 \%$ golden berry juice via an epigastric tube for 8 weeks. Dosage of yogurt drink treated was $5 \mathrm{~mL} / \mathrm{mouse}$.

\subsection{Blood Sampling and Biochemical Analyses}

At the end of the trial term (8 weeks), all rats were fasted overnight before sacrificing. Blood samples were collected from the hepatic portal vein; one part was used for various analyses, and the remaining blood was kept in a centrifuge tube at room temperature for $15 \mathrm{~min}$ and then centrifuged at $4000 \mathrm{rpm}$ for $10 \mathrm{~min}$, to obtain serum, which was placed in plastic vials and stored at $-20{ }^{\circ} \mathrm{C}$ until analysis. Subsequently, the livers were dissected, washed, and homogenized immediately to yield a $50 \%(w / v)$ homogenate in 
ice-cold medium containing $50 \mathrm{mM}$ Tris- $\mathrm{HCl}, \mathrm{pH}$ 7.4. The homogenate was centrifuged at $3000 \mathrm{rpm}$ for $10 \mathrm{~min}$ at $4{ }^{\circ} \mathrm{C}$. The supernatant $(10 \%)$ was used in the various biochemical determinations.

\subsection{Biochemical Analysis}

Serum alanine aminotransferase (ALT) or aspartate aminotransferase (AST) was assayed according to Reitman and Frankel [44]. Alkaline phosphatase (ALP) was assayed according to Belfield and Goldberg [45]. $\gamma$-Glutamyltransferase $(\gamma-G T)$ was assessed according to Szasz and Persijn [46]. Moreover, total bilirubin (TB) in serum was assayed according to Garber [47]. The total antioxidant capacity (TAC) was determined according to Koracevic et al. [48]. Liver catalase (CAT) and Superoxide dismutase (SOD) activities were determined according to [49] and Nishikimi et al. [50], respectively. Malondialdehyde (MDA) was assayed in serum and homogenates of the liver according to Ohkawa et al. [51], whereas glutathione (GSH) was measured as described elsewhere [52].

\subsection{Statistical Analysis}

Data were statistically analyzed using the Statistic software, version 9 [53], and the differences between the means of the treatments were considered significant when they were greater than the least significant differences at the $5 \%$ level.

\section{Results and Discussion}

\subsection{Approximate Composition of the Golden Berry Juice}

Table 1 presents the approximate chemical composition of the golden berry juice. The moisture, protein, fat, and ash contents of the golden berry juice were 88.40, 1.06, 0.16 , and $0.80 \mathrm{~g} / 100 \mathrm{~g}$, respectively. The total phenolic, ascorbic acid, and carotenoid contents, and the \% DPPH inhibition of the golden berry juice were $112.40 \mathrm{mg}$ GAE $/ 100 \mathrm{~mL}$, $52.68 \mathrm{mg} / 100 \mathrm{~mL}, 86.54 \mu \mathrm{g} / \mathrm{mL}$, and $78.34 \%$, respectively. These results of chemical composition were in line with those reported by El Sheikha et al. [54,55], who found that the moisture, protein, fat, and ash contents of golden berry juice were 89.34, 1.02, 0.13, and $0.75 \mathrm{~g} / 100 \mathrm{~g}$, respectively, but in the same study, the results of the total phenolic, ascorbic acid and carotenoids contents of golden berry juice were slightly different from the results we reached, where the total phenolic, ascorbic acid, and carotenoid contents of golden berry juice were $76.60 \mathrm{mg}$ GAE/100 mL, $38.77 \mathrm{mg} / 100 \mathrm{~mL}$, and $70.0 \mu \mathrm{g} \mathrm{mL}^{-1}$, respectively.

Table 1. Approximate chemical composition (total phenol, ascorbic acid, and carotenoid content) and $\%$ DPPH inhibition of golden berry juice.

\begin{tabular}{cc}
\hline Components (\%) & Golden Berry Juice \\
\hline Moisture & 88.40 \\
\hline Protein & 1.06 \\
\hline Fat & 0.16 \\
\hline Ash & 0.80 \\
\hline Total phenol $(\mathrm{mg} \mathrm{GAE} / 100 \mathrm{~mL})$ & 112.40 \\
\hline Ascorbic acid $(\mathrm{mg} / 100 \mathrm{~mL})$ & 52.68 \\
\hline Carotenoids $\left(\mu \mathrm{g} \mathrm{mL} \mathrm{m}^{-1}\right)$ & 86.54 \\
\hline \% DPPH Inhibition & 78.34 \\
\hline
\end{tabular}

\subsection{Chemical Composition of a Yogurt Drink Fortified with Golden Berry Juice}

Table 2 shows that fortification of a yogurt drink with golden berry juice increased the TS content in the fortified yogurt drink, whereas the protein, fat, and ash contents of the yogurt drink were not affected by fortification with golden berry juice at two ratios, which may be due to the low protein, fat, and ash contents of golden berry juice [55]. This result 
agrees with that of Ismail et al. (2020) [33], who found that the fortification of a yogurt drink with fruit juices (red grape or apricot) increased the TS but did not affect the protein, fat, and ash contents of the resultant yogurt drink.

Table 2. Chemical composition of a yogurt drink fortified with golden berry juice on the first day of storage.

\begin{tabular}{ccccc}
\hline \multirow{2}{*}{ Components (\%) } & \multicolumn{4}{c}{ Treatments } \\
\cline { 2 - 5 } & $\mathbf{C}$ & $\mathbf{T}_{\mathbf{1}}$ & $\mathbf{T}_{\mathbf{2}}$ & LSD \\
\hline Total solids & $11.70^{\mathrm{C}}$ & $12.78^{\mathrm{B}}$ & $13.84^{\mathrm{A}}$ & 0.1681 \\
\hline Protein & $2.12^{\mathrm{A}}$ & $2.24^{\mathrm{A}}$ & $2.46^{\mathrm{A}}$ & 0.6162 \\
\hline Fat & $1.25^{\mathrm{A}}$ & $1.28^{\mathrm{A}}$ & $1.30^{\mathrm{A}}$ & 0.1269 \\
\hline Ash & $0.50^{\mathrm{A}}$ & $0.56^{\mathrm{A}}$ & $0.64^{\mathrm{A}}$ & 0.1513 \\
\hline
\end{tabular}

Means followed by different uppercase letters in the same column are significantly different $(p \leq 0.05)$. LSD, least significant difference; $\mathrm{C}$, yogurt drink made from cow milk, as a control (C); $\mathrm{T}_{1}$, yogurt drink fortified with $10 \%$ golden berry juice; $\mathrm{T}_{2}$, yogurt drink fortified with $20 \%$ golden berry juice.

3.3. Titratable Acidity, $p H$ Values, TPC, and \% DPPH Inhibition of a Yogurt Drink Fortified with Golden Berry Juice

Table 3 indicates that the control yogurt drink had the lowest titratable acidity (TA) value. The acidity of the yogurt drink fortified with golden berry juice increased as the fortification ratio increased, which may be due to the high TA of golden berry juice [56]. Accordingly, the $\mathrm{pH}$ values of all treatments exhibited a reverse trend compared with that observed for TA because they expressed the level of alkalinity. Similar results were obtained by Dimitrellou et al. (2020) [11], who found that the fortification of yogurt with juices from grapes and berries increased the TA values of the resultant yogurt.

Table 3. Titratable acidity, $\mathrm{pH}$ values, total phenolic content, and \% DPPH inhibition of a yogurt drink fortified with golden berry juice on the first day of storage.

\begin{tabular}{ccccc}
\hline \multirow{2}{*}{ Parameters } & \multicolumn{4}{c}{ Treatments } \\
\cline { 2 - 5 } & $\mathbf{C}$ & $\mathbf{T}_{\mathbf{1}}$ & $\mathbf{T}_{\mathbf{2}}$ & LSD \\
\hline Acidity\% & $0.45^{\mathrm{C}}$ & $0.62^{\mathrm{B}}$ & $0.75^{\mathrm{A}}$ & 0.1177 \\
\hline $\mathrm{pH}$ values & $6.02^{\mathrm{A}}$ & $5.37^{\mathrm{AB}}$ & $4.72^{\mathrm{B}}$ & 1.0176 \\
\hline Ascorbic acid $(\mathrm{mg} / 100 \mathrm{~mL})$ & $0.78^{\mathrm{C}}$ & $4.34^{\mathrm{B}}$ & $6.92^{\mathrm{A}}$ & 1.798 \\
\hline Carotenoids $(\mu \mathrm{g} / \mathrm{mL})$ & $0.84^{\mathrm{C}}$ & $7.40^{\mathrm{B}}$ & $11.78^{\mathrm{A}}$ & 1.748 \\
\hline TPC $(\mathrm{mg} / 100 \mathrm{~g})$ & $15.33^{\mathrm{C}}$ & $24.72^{\mathrm{B}}$ & $36.84^{\mathrm{A}}$ & 1.680 \\
\hline$\%$ DPPH Inhibition & $11.46^{\mathrm{C}}$ & $19.54^{\mathrm{B}}$ & $28.60^{\mathrm{A}}$ & 6.723
\end{tabular}

Means followed by different uppercase letters in the same column are significantly different ( $p \leq 0.05)$. LSD, least significant difference.

The ascorbic acid, carotenoid, and TPCs and the \% DPPH inhibition of the yogurt drink supplemented with golden berry juice increased as the supplementation ratio increased, compared with the control yogurt drink (Table 3). This may be due to the high ascorbic acid, carotenoid, and TPC of the golden berry fruit and juice [23,55]. These results agreed with those reported by Dimitrellou et al. [11], who found that the TPC and radical scavenging activity of yogurt increased after the fortification of yogurt milk with juices from grapes and berries. Moreover, Naeem et al. [56] found that fortification of ice cream with concentrated golden berry juice increased its total phenolic content and radical scavenging activity.

\subsection{Sensory Properties of a Yogurt Drink Fortified with Golden Berry Juice}

The data presented in Table 4 showed that the fortification of a yogurt drink with golden berry juice increased greatly the sensory attributes of the resultant yogurt drink, especially 
its taste, odor, and overall acceptance compared with the control yogurt drink; moreover, this increment was proportional to the fortification ratios. All treatments yielded acceptable sensory properties. These results agree with those reported by Dimitrellou et al. [11], who observed a great improvement in the sensory properties of yogurt after fortification with juices from grapes and berries. Moreover, Naeem et al. [56] found that the fortification of ice cream with concentrated golden berry juice improved greatly its sensory properties.

Table 4. Sensory properties of a yogurt drink fortified with golden berry juice on the first day of storage.

\begin{tabular}{ccccc}
\hline \multirow{2}{*}{ Items } & \multicolumn{4}{c}{ Treatments } \\
\cline { 2 - 5 } & $\mathbf{C}$ & $\mathbf{T}_{\mathbf{1}}$ & $\mathbf{T}_{\mathbf{2}}$ & LSD \\
\hline Taste & $3.90^{\mathrm{C}}$ & $4.70^{\mathrm{B}}$ & $5.0^{\mathrm{A}}$ & 0.1681 \\
\hline Odor & $3.70^{\mathrm{B}}$ & $4.30^{\mathrm{AB}}$ & $4.80^{\mathrm{A}}$ & 0.6724 \\
\hline Appearance & $4.80^{\mathrm{B}}$ & $4.50^{\mathrm{AB}}$ & $4.30^{\mathrm{A}}$ & 0.3362 \\
\hline Overall acceptance & $3.90^{\mathrm{C}}$ & $4.40^{\mathrm{B}}$ & $4.90^{\mathrm{A}}$ & 0.1681 \\
\hline
\end{tabular}

Means followed by different uppercase letters in the same column are significantly different $(p \leq 0.05)$. LSD, Least significant difference.

\subsection{Effect of a Yogurt Drink Fortified with Golden Berry Juice on Serum AST, ALT, $\gamma$-GT, ALP,} and $T B$ Levels in Rats with Hepatitis

The effects of the treatments described above on the levels of AST, ALT, $\gamma$-GT, ALP, and TB are illustrated in Table 5. The negative control group showed significantly low serum AST, A LT, $\gamma$-GT, ALP, and TB levels compared with the hepatitis rat group. The lowest mean values of AST, ALT, $\gamma$-GT, ALP, and TB in the negative control (Group 1) were $74.14 \mathrm{U} / \mathrm{mL}, 60.22 \mathrm{U} / \mathrm{mL}, 138.40 \mathrm{U} / \mathrm{mL}, 40.02 \mathrm{U} / \mathrm{mL}$, and $3.04 \mathrm{mg} / \mathrm{dL}$, respectively. In contrast, the two rat groups that were fed a yogurt drink containing golden berry juice (Groups 4 and 5) exhibited a significant reduction in AST, ALT, $\gamma$-GT, ALP, and TB levels compared with the hepatitis positive control group (Group 2). Furthermore, the rats with hepatitis had significantly higher levels of AST, ALT, $\gamma$-GT, ALP, and TB than did the control rats. In turn, rats with hepatitis that were fed a yogurt drink containing $20 \%$ golden berry juice exhibited non-significant differences in AST, ALT, $\gamma$-GT, ALP, and TB levels compared with the control rats. The best improvement after treatment was observed in the group that consumed the yogurt drink containing $20 \%$ golden berry juice, which may be due to the general chemical composition of golden berry juice, which has antiproliferative effects on hepatoma cells [57], antihepatotoxic effects [58], antioxidant activity [25], and antiinflammatory activity [59]. The hepatoprotective effect may be attributed to the presence of ascorbic acid and phenolic components, such as chlorogenic, ferulic, caffeic, gallic, and p-coumaric acids, as well as flavonoids, such as kaempferol, catechin, epicatechin rutin, myricetin, and quercetin $[27,60]$, which are well-known hepatoprotective agents [60]. The first indication of the liver damage caused by $\mathrm{CCl}_{4}$ can be obtained by assessing ALT, AST, ALP, and $\gamma$-GT levels, as these enzymes are upregulated in cytotoxic liver injury and cholestasis. Golden berry juice is a clear indication for the improvement of the functional status of liver cells while preserving cellular architecture [61], which confirms the protective activity of golden berries on the liver. The data were in line with those of Al-Olayan et al. [2], who reported that golden berry juice showed a potential protective effect against $\mathrm{CCl}_{4^{-}}$ induced hepatotoxicity in rats. Furthermore, Taj et al. [62] found that animals treated/fed with various preparations of golden berries exhibited a significant decrease in the elevated levels of serum markers, such as ALAT, ASAT, ALP, LDH, creatinine, urea, and bilirubin, indicating protection against hepatic cell damage. 
Table 5. Effect of a yogurt drink fortified with golden berry juice on serum ALT, AST, ALP, and $\gamma$-GT activities in rats with hepatitis.

\begin{tabular}{ccccccc}
\hline \multirow{2}{*}{ Parameters } & \multicolumn{7}{c}{ Groups } \\
\cline { 2 - 6 } & Group 1 & Group 2 & Group 3 & Group 4 & Group 5 & LSD \\
\hline AST $(\mathrm{U} / \mathrm{mL})$ & $74.14^{\mathrm{C}}$ & $156.70^{\mathrm{A}}$ & $86.24^{\mathrm{B}}$ & $80.46^{\mathrm{B}}$ & $76.84^{\mathrm{BC}}$ & 11.192 \\
\hline ALT $(\mathrm{U} / \mathrm{mL})$ & $60.22^{\mathrm{D}}$ & $128.52^{\mathrm{A}}$ & $96.60^{\mathrm{B}}$ & $84.32^{\mathrm{C}}$ & $66.50^{\mathrm{D}}$ & 9.036 \\
\hline ALP $(\mathrm{IU} / \mathrm{L})$ & $138.40^{\mathrm{D}}$ & $240.84^{\mathrm{A}}$ & $190.62^{\mathrm{B}}$ & $170.24^{\mathrm{BC}}$ & $146.30^{\mathrm{CD}}$ & 29.848 \\
\hline$\gamma-\mathrm{GT}(\mathrm{U} / \mathrm{L})$ & $40.02^{\mathrm{C}}$ & $54.86^{\mathrm{A}}$ & $48.24^{\mathrm{B}}$ & $43.58^{\mathrm{BC}}$ & $40.60^{\mathrm{C}}$ & 4.887 \\
\hline TB $(\mathrm{mg} / \mathrm{dL})$ & $3.04^{\mathrm{D}}$ & $6.22^{\mathrm{A}}$ & $4.20^{\mathrm{B}}$ & $3.78^{\mathrm{C}}$ & $3.22^{\mathrm{C}}$ & 0.2768 \\
\hline
\end{tabular}

Means followed by different uppercase letters in the same column are significantly different $(p \leq 0.05)$. LSD: Least significant difference. Group 1: Negative control rats fed a basal diet. ALT: Serum Alaninealanine aminotransferase; AST: aspartate aminotransferase; ALP: Alkaline phosphatase; $\gamma$-GT: $\gamma$-Glutamyltransferase; TB: total bilirubin. Group 2: Hepatitis rats (as a positive control group) fed a basal diet. Group 3: Hepatitis rats fed a basal diet with $5 \mathrm{~mL}$ of a yogurt drink. Group 4: Hepatitis rats fed a basal diet with $5 \mathrm{~mL}$ of a yogurt drink fortified with $10 \%$ golden berry juice. Group 5 : Hepatitis rats fed a basal diet with $5 \mathrm{~mL}$ of a yogurt drink fortified with $20 \%$ golden berry juice.

It is noteworthy to mention that understanding the sex's similarities, differences, and/or complex seems crucial for correctly applying research-derived knowledge. The present study pointed out the use of male rats were used in the experiment since there was a great concern among scientists about including female animals in preclinical biomedical research for fear of increasing costs and diversity in the resulting data [63]. In this concern, a previous study [64] revealed that biomedical research might be affected by the impact of the animal's sex on the cellular, molecular and biochemical levels. Importantly, there is substantial bias in biomedical research to not study female rats/mice $[65,66]$. The exclusion of female rats/mice in biological research was justified due to the variable physiological nature of female data caused by hormonal fluctuations associated with the female's reproductive cycle. However, it should be stressed also that some recent studies documented that female mice were not inherently more variable than male mice across diverse physiological traits [67]. Regardless of which sex was used in the present work, including both sexes in the same experiment might influence the findings and the resulting data. Furthermore, several previous studies used male rats/mice in hepatitis in rats [68-71].

3.6. Effect of a Yogurt Drink Fortified with Golden Berry Juice on Serum MDA, GSH, and TAC and Liver MDA, GSH, CAT, and SOD Levels in Rats with Hepatitis

The data illustrated in Table 6 showed that the rats with hepatitis had significantly lower serum GSH and CAT levels and lower serum MDA values compared with the control rats. The groups of rats with hepatitis that were fed the yogurt drink fortified with golden berry juice showed a significant increase in serum GSH and CAT levels and a decrease in serum MDA levels compared with the hepatitis positive control rats. This represented evidence of the protective effect of the yogurt drink fortified with golden berry juice in the liver. Moreover, the rats with hepatitis had significantly lower liver SOD, CAT, and GSH levels and a higher liver MDA level compared with the control rats. The groups of rats with hepatitis that were fed a yogurt drink fortified with golden berry juice exhibited a significant increase in liver SOD, GSH, and CAT levels and a decrease in the liver MDA level compared with the hepatitis positive control rats. These improvements indicated that the yogurt drink fortified with golden berry juice exerted antioxidative and beneficial effects regarding liver recovery from $\mathrm{CCl}_{4}$ injury. 
Table 6. Effect of a yogurt drink fortified with golden berry juice on serum MDA, GSH, and TCA and Liver MDA, GSH, CAT, and SOD levels in rats with hepatitis.

\begin{tabular}{ccccccc}
\hline \multirow{2}{*}{ Parameters } & \multicolumn{5}{c}{ Groups } \\
\cline { 2 - 6 } & Group 1 & Group 2 & Group 3 & Group 4 & Group 5 & LSD \\
\hline $\begin{array}{c}\text { Serum MDA } \\
(\mathrm{nmol} / \mathrm{mL})\end{array}$ & $35.22^{\mathrm{C}}$ & $52.48^{\mathrm{A}}$ & $42.84^{\mathrm{B}}$ & $38.60^{\mathrm{BC}}$ & $36.54^{\mathrm{C}}$ & 5.043 \\
\hline $\begin{array}{c}\text { Serum GSH } \\
(\mathrm{mmol} / \mathrm{mL})\end{array}$ & $65.40^{\mathrm{B}}$ & $36.72^{\mathrm{E}}$ & $58.26^{\mathrm{D}}$ & $62.86^{\mathrm{C}}$ & $68.38^{\mathrm{A}}$ & 1.259 \\
\hline $\begin{array}{c}\text { Serum TAC } \\
(\mathrm{mmol} / \mathrm{L})\end{array}$ & $0.94^{\mathrm{A}}$ & $0.58^{\mathrm{D}}$ & $0.66^{\mathrm{CD}}$ & $0.74^{\mathrm{BC}}$ & $0.82^{\mathrm{B}}$ & 0.1168 \\
\hline $\begin{array}{c}\text { Liver MDA } \\
(\text { nmol/g tissue })\end{array}$ & $412.86^{\mathrm{D}}$ & $574.50^{\mathrm{A}}$ & $486.24^{\mathrm{B}}$ & $442.66^{\mathrm{C}}$ & $404.80^{\mathrm{E}}$ & 7.342 \\
\hline $\begin{array}{c}\text { Liver GSH } \\
(\mathrm{mmol} / \mathrm{g} \mathrm{tissue})\end{array}$ & $38.30^{\mathrm{B}}$ & $24.52^{\mathrm{D}}$ & $32.62^{\mathrm{C}}$ & $40.06^{\mathrm{B}}$ & $46.74^{\mathrm{A}}$ & 3.084 \\
\hline $\begin{array}{c}\text { Liver CAT } \\
(\mathrm{U} / \mathrm{g})\end{array}$ & $92.46^{\mathrm{B}}$ & $65.30^{\mathrm{E}}$ & $73.84^{\mathrm{D}}$ & $86.22^{\mathrm{C}}$ & $96.20^{\mathrm{A}}$ & 1.542 \\
\hline $\begin{array}{c}\text { Liver SOD } \\
(\mathrm{U} / \mathrm{g})\end{array}$ & $132.82^{\mathrm{A}}$ & $66.14^{\mathrm{E}}$ & $80.76^{\mathrm{D}}$ & $94.60^{\mathrm{C}}$ & $104.54^{\mathrm{B}}$ & 6.169
\end{tabular}

Means followed by different uppercase letters in the same column are significantly different $(p \leq 0.05)$. LSD: Least significant difference. TAC: total antioxidant capacity; CAT: Liver catalase (CAT); SOD: Superoxide dismutase; MDA Malondialdehyde; GSH: glutathione (GSH). Group 1: Negative control rats fed a basal diet Group 2: Hepatitis rats (as a positive control group) fed a basal diet. Group 3: Hepatitis rats fed a basal diet with $5 \mathrm{~mL}$ of a yogurt drink. Group 4: Hepatitis rats fed a basal diet with $5 \mathrm{~mL}$ of a yogurt drink fortified with $10 \%$ golden berry juice. Group 5: Hepatitis rats fed a basal diet with $5 \mathrm{~mL}$ of a yogurt drink fortified with $20 \%$ golden berry juice.

The toxicity of $\mathrm{CCl}_{4}$ is due to oxidative stress caused by free radicals, which contributes to both the onset and development of fibrosis. This appears during lipid peroxidation, which is associated with a decrease in the levels of GSH and the antioxidant enzymes SOD, CAT, and GSH [5,72]. These enzymes constitute a strong defense against ROS [73].

The yogurt drink fortified with golden berry juice attenuated the intoxication effects triggered by $\mathrm{CCl}_{4}$ and significantly improved the activity of these enzymes, which indicates the antihepatotoxic and antioxidant effects of golden berry juice, similar to the results obtained elsewhere [2]. Ascorbic acid and the phenolic components present in golden berries, such as chlorogenic, ferulic, caffeic, gallic, and p-coumaric acids, as well as flavonoids, such as kaempferol, catechin, epicatechin rutin, myricetin, and quercetin, may explain the antioxidant activity recorded in golden berries, which are considered to be a strong antioxidant because of their ability to scavenge free radicals and active oxygen species [74]. These properties of phenolic and flavonoid compounds allow them to inhibit lipid peroxidation and exert anti-inflammatory effects $[5,75]$.

\section{Conclusions}

Collectively, the golden berry fruit juice showed high contents from total phenol (112.40 mg GAE/100 mL), ascorbic acid (52.86 mg/100 mL $\mathrm{mL}^{-1}$ ) and carotenoids $\left(86.54 \mu \mathrm{g} / \mathrm{mL}^{-1}\right)$. Based on the results presented above, the golden berry fruit juice can be used to fortify several vital food products, such as yogurt drinks. The addition of golden berry fruit juice, up to a concentration of $20 \%$, during the manufacture of yogurt drinks did not affect the contents of protein, fat and ash, while it greatly affected the total sensorial preference, acidity values, total phenolic content and antioxidant activity, and added health benefits to them because of its highly bioactive components. Yogurt drinks fortified with golden berry juice proved effective in protecting against hepatitis in albino rats. The bioactive components of golden berry juice were able to prevent hepatitis in rats by lowering the levels of several relevant parameters, i.e., markers of liver function, and upregulating the antioxidant enzymes SOD, CAT, and GSH. Therefore, golden berry juice can be recommended as a natural additive in the manufacture of functional yogurt drinks. 


\begin{abstract}
Author Contributions: M.R.S., E.S.H.A., H.A.R. and A.A.E. were involved in the conception of the research idea and methodology design, supervision, and performed data analysis and interpretation. A.A.H., A.A. and E.K.E. were involved in methodology, and drafted and prepared the manuscript for publication and revision. All authors have read and agreed to the published version of the manuscript. The funders had no role in data collection and analysis, decision to publish, or preparation of the manuscript.
\end{abstract}

Funding: This research received no external funding.

Institutional Review Board Statement: This study was conducted with the approval of the approval of the Faculty of Veterinary Medicine, Suez Canal University and the institutional Review Board Number 2021048.

Informed Consent Statement: Not applicable.

Data Availability Statement: The data that support the findings of this study are available on request from the corresponding author.

Acknowledgments: The authors thank the Taif University Researchers Supporting Program (Project number: TURSP-2020/151), Taif University, Saudi Arabia for support.

Conflicts of Interest: The authors declare no conflict of interest.

\title{
References
}

1. Asrani, S.K.; Devarbhavi, H.; Eaton, J.; Kamath, P.S. Burden of liver diseases in the world. J. Hepatol. 2019, 70, 151-171. [CrossRef] [PubMed]

2. Al-Olayan, E.M.; El-Khadragy, M.F.; Aref, A.M.; Othman, M.S.; Kassab, R.B.; Abdel Moneim, A.E. The potential protective effect of Physalis peruviana L. against carbon tetrachloride-induced hepatotoxicity in rats is mediated by suppression of oxidative stress and downregulation of MMP-9 expression. Oxidative Med. Cell. Longev. 2014, 2014, 381413. [CrossRef] [PubMed]

3. Hikal, A.H.; Abd El-Fatta, H.; El-Sheik, N.; Refaie, A.A. Comparative study of marjoram (Origanum majorana L.) and silymarin (Silybum marianum L.) extract against carbon tetrachloride induced hepatic injury. World J. Pharm. Pharm. Sci. 2018, 7, 1969-1992.

4. Arauz, J.; Rivera-Espinoza, Y.; Shibayama, M.; Favari, L.; Flores-Beltrán, R.E.; Muriel, P. Nicotinic acid prevents experimental liver fibrosis by attenuating the prooxidant process. Int. Immunopharmacol. 2015, 28, 244-251. [CrossRef]

5. Ramos-Tovar, E.; Muriel, P. Molecular mechanisms that link oxidative stress, inflammation, and fibrosis in the liver. Antioxidants 2020, 9, 1279. [CrossRef]

6. Casas-Grajales, S.; Reyes-Gordillo, K.; Cerda-García-Rojas, C.M.; Tsutsumi, V.; Lakshman, M.R.; Muriel, P. Rebaudioside A administration prevents experimental liver fibrosis: An in vivo and in vitro study of the mechanisms of action involved. J. Appl. Toxicol. 2019, 39, 1118-1131. [CrossRef]

7. Chen, Z.; Tian, R.; She, Z.; Cai, J.; Li, H. Role of oxidative stress in the pathogenesis of nonalcoholic fatty liver disease. Free Radic. Biol. Med. 2020, 152, 116-141. [CrossRef]

8. Fu, Y.; Zheng, S.; Lin, J.; Ryerse, J.; Chen, A. Curcumin protects the rat liver from CCl4-caused injury and fibrogenesis by attenuating oxidative stress and suppressing inflammation. Mol. Pharmacol. 2008, 73, 399-409. [CrossRef]

9. Deng, G.; Wang, J.; Zhang, Q.; He, H.; Wu, F.; Feng, T.; Zhou, J.; Zou, K.; Hattori, M. Hepatoprotective effects of phloridzin on hepatic fibrosis induced by carbon tetrachloride against oxidative stress-triggered damage and fibrosis in rats. Biol. Pharm. Bull. 2012, 35, 1118-1125. [CrossRef]

10. Thuy, T.; Hai, H.; Kawada, N. Role of oxidative and nitrosative stress in hepatic fibrosis. In Liver Pathophysiology; Elsevier: Amsterdam, The Netherlands, 2017; pp. 213-224.

11. Dimitrellou, D.; Solomakou, N.; Kokkinomagoulos, E.; Kandylis, P. Yogurts supplemented with juices from grapes and berries. Foods 2020, 9, 1158. [CrossRef]

12. Bimbo, F.; Bonanno, A.; Nocella, G.; Viscecchia, R.; Nardone, G.; De Devitiis, B.; Carlucci, D. Consumers' acceptance and preferences for nutrition-modified and functional dairy products: A systematic review. Appetite 2017, 113, 141-154. [CrossRef] [PubMed]

13. Atwaa, E.S.H.; Shahein, M.R.; El-Sattar, E.S.A.; Hijazy, H.H.A.; Albrakati, A.; Elmahallawy, E.K. Bioactivity, Physicochemical and Sensory Properties of Probiotic Yoghurt Made from Whole Milk Powder Reconstituted in Aqueous Fennel Extract. Fermentation 2022, 8, 52. [CrossRef]

14. Shahein, M.R.; Atwaa, E.S.H.; El-Zahar, K.M.; Elmaadawy, A.A.; Hijazy, H.H.A.; Sitohy, M.Z.; Albrakati, A.; Elmahallawy, E.K. Remedial Action of Yoghurt Enriched with Watermelon Seed Milk on Renal Injured Hyperuricemic Rats. Fermentation $2022,8,41$. [CrossRef]

15. Swelam, S.; Zommara, M.A.; Abd El-Aziz, A.E.-A.M.; Elgammal, N.A.; Baty, R.S.; Elmahallawy, E.K. Insights into Chufa Milk Frozen Yoghurt as Cheap Functional Frozen Yoghurt with High Nutritional Value. Fermentation 2021, 7, 255. [CrossRef]

16. Beltrán-Barrientos, L.; Hernández-Mendoza, A.; Torres-Llanez, M.; González-Córdova, A.; Vallejo-Córdoba, B. Invited review: Fermented milk as antihypertensive functional food. J. Dairy Sci. 2016, 99, 4099-4110. [CrossRef] 
17. Szilagyi, A.; Ishayek, N. Lactose intolerance, dairy avoidance, and treatment options. Nutrients 2018, 10, 1994. [CrossRef]

18. Munekata, P.E.; Domínguez, R.; Budaraju, S.; Roselló-Soto, E.; Barba, F.J.; Mallikarjunan, K.; Roohinejad, S.; Lorenzo, J.M. Effect of innovative food processing technologies on the physicochemical and nutritional properties and quality of non-dairy plant-based beverages. Foods 2020, 9, 288. [CrossRef]

19. Aryana, K.J.; Olson, D.W. A 100-Year Review: Yogurt and other cultured dairy products. J. Dairy Sci. 2017, 100, 9987-10013. [CrossRef]

20. Khan, M.Z.; Shabbir, M.I.; Saqib, Z.; Gilani, S.A.; Jogezai, N.U.; Kiyani, M.M.; Malik, M.A. Investigation of polyphenol profile, antioxidant activity and hepatoprotective potential of Aconogonon alpinum (All.) Schur roots. Open Chem. 2020, 18, 516-536. [CrossRef]

21. Othman, M.S.; Nada, A.; Zaki, H.S.; Moneim, A.E.A. Effect of Physalis peruviana L. on cadmium-induced testicular toxicity in rats. Biol. Trace Elem. Res. 2014, 159, 278-287. [CrossRef]

22. Grigolo, C.R.; Oliveira, M.d.C.; Loss, E.S.; Ropelato, J.; Oldoni, T.; Batista, C.B. Physico-chemical characterization and antioxidant content of Physalis fruits. Rev. Mex. Cienc. Agríc. 2020, 11, 607-618. [CrossRef]

23. Ezzat, S.M.; Abdallah, H.M.; Yassen, N.N.; Radwan, R.A.; Mostafa, E.S.; Salama, M.M.; Salem, M.A. Phenolics from Physalis peruviana fruits ameliorate streptozotocin-induced diabetes and diabetic nephropathy in rats via induction of autophagy and apoptosis regression. Biomed. Pharmacother. 2021, 142, 111948. [CrossRef] [PubMed]

24. Fang, S.-T.; Liu, J.-K.; Li, B. Ten new withanolides from Physalis peruviana. Steroids 2012, 77, 36-44. [CrossRef] [PubMed]

25. Dong, B.; An, L.; Yang, X.; Zhang, X.; Zhang, J.; Tuerhong, M.; Jin, D.-Q.; Ohizumi, Y.; Lee, D.; Xu, J. Withanolides from Physalis peruviana showing nitric oxide inhibitory effects and affinities with iNOS. Bioorganic Chem. 2019, 87, 585-593. [CrossRef]

26. Llano, S.M.; Muñoz-Jiménez, A.M.; Jiménez-Cartagena, C.; Londoño-Londoño, J.; Medina, S. Untargeted metabolomics reveals specific withanolides and fatty acyl glycoside as tentative metabolites to differentiate organic and conventional Physalis peruviana fruits. Food Chem. 2018, 244, 120-127. [CrossRef]

27. Olivares-Tenorio, M.-L.; Dekker, M.; Verkerk, R.; van Boekel, M.A. Health-promoting compounds in cape gooseberry (Physalis peruviana L.): Review from a supply chain perspective. Trends Food Sci. Technol. 2016, 57, 83-92. [CrossRef]

28. Rahimzadeh, G.; Tay, A.; Mac Regenstein, J.; Rokhzadi, A.; Dabiri, H. Evaluation of microbial and sensory properties of flavored yogurt drink produced by Noaea mucronata and liquid smoke treatment. Infect. Dis. Herb. Med. 2020, 77, 5-10. [CrossRef]

29. Teles, C.D.; Flores, S.H. The influence of additives on the rheological and sensory properties of nonfat yogurt. Int. J. Dairy Technol. 2007, 60, 270-276. [CrossRef]

30. Kamel, D.G.; Othman, A.A.; Osman, D.M.; Hammam, A.R. Probiotic yogurt supplemented with nanopowdered eggshell: Shelf-life stability, physicochemical, and sensory characteristics. Food Sci. Nutr. 2021, 9, 1736-1742. [CrossRef]

31. de Campo, C.; Assis, R.Q.; da Silva, M.M.; Costa, T.M.H.; Paese, K.; Guterres, S.S.; de Oliveira Rios, A.; Flôres, S.H. Incorporation of zeaxanthin nanoparticles in yogurt: Influence on physicochemical properties, carotenoid stability and sensory analysis. Food Chem. 2019, 301, 125230. [CrossRef]

32. Kamel, D.G.; Hammam, A.R.; Alsaleem, K.A.; Osman, D.M. Addition of inulin to probiotic yogurt: Viability of probiotic bacteria (Bifidobacterium bifidum) and sensory characteristics. Food Sci. Nutr. 2021, 9, 1743-1749. [CrossRef] [PubMed]

33. Ismail, E.; Shenana, M.; Elalfy, M.; Essawy, E.; Abdelhahim, S. Novel Probiotic Adjunct Cultures for the Production of FruitFlavoured Drinkable Yoghurt. Egypt. J. Food Sci. 2020, 48, 213-228. [CrossRef]

34. Reeves, P.G.; Nielsen, F.H.; Fahey, G.C., Jr. AIN-93 Purified Diets for Laboratory Rodents: Final Report of the American Institute of Nutrition ad Hoc Writing Committee on the Reformulation of the AIN-76A Rodent Diet; Oxford University Press: Oxford, UK, 1993.

35. Odabasoglu, F.; Aslan, A.; Cakir, A.; Suleyman, H.; Karagoz, Y.; Halici, M.; Bayir, Y. Comparison of antioxidant activity and phenolic content of three lichen species. Phytother. Res. 2004, 18, 938-941. [CrossRef] [PubMed]

36. Illupapalayam, V.V.; Smith, S.C.; Gamlath, S. Consumer acceptability and antioxidant potential of probiotic-yogurt with spices. LWT-Food Sci. Technol. 2014, 55, 255-262. [CrossRef]

37. Maksimović, Z.; Malenčić, Đ.; Kovačević, N. Polyphenol contents and antioxidant activity of Maydis stigma extracts. Bioresour Technol. 2005, 96, 873-877. [CrossRef]

38. Apostolidis, E.; Kwon, Y.-I.; Shetty, K. Inhibitory potential of herb, fruit, and fungal-enriched cheese against key enzymes linked to type 2 diabetes and hypertension. Innov. Food Sci. Emerg. Technol. 2007, 8, 46-54. [CrossRef]

39. Bajaj, K.; Kaur, G. Spectrophotometric determination of L-ascorbic acid in vegetables and fruits. Analyst 1981, 106, 117-120. [CrossRef]

40. Horwitz, W. (Ed.) Agricultural Chemicals, Contaminants, Drugs. In Official Methods of Analysis of AOAC International; AOAC International: Gaithersburg, MD, USA, 2010; Volume I.

41. Thomas, N.; Wansapala, M. Utilization of green tea (Camellia sinensis) extract for the production of antioxidant rich functional drinking yoghurt. Int. J. Food Sci. Nutr. 2017, 2, 188-195.

42. Heymann, H.; Lawless, H.T. Sensory Evaluation of Food: Principles and Practices; Springer Science \& Business Media: Berlin/Heidelberg, Germany, 2013.

43. Jayasekhar, P.; Mohanan, P.; Rathinam, K. Hepatoprotective activity of ethyl acetate extract of Acacia catechu. Indian J. Pharm. $1997,29,426$

44. Reitman, S.; Frankel, S. A colorimetric method for the determination of serum glutamic oxalacetic and glutamic pyruvic transaminases. Am. J. Clin. Pathol. 1957, 28, 56-63. [CrossRef] 
45. Belfield, A.; Goldberg, D. Revised assay for serum phenyl phosphatase activity using 4-amino-antipyrine. Enzyme 1971, 12, 561-573. [CrossRef] [PubMed]

46. Szasz, G. A kinetic photometric method for serum $\gamma$-glutamyl transpeptidase. Clin. Chem. 1969, 15, 124-136. [CrossRef] [PubMed]

47. Garber, C.C. Jendrassik-Grof analysis for total and direct bilirubin in serum with a centrifugal analyzer. Clin. Chem. 1981, 27, 1410-1416. [CrossRef] [PubMed]

48. Koracevic, D.; Koracevic, G.; Djordjevic, V.; Andrejevic, S.; Cosic, V. Method for the measurement of antioxidant activity in human fluids. J. Clin. Pathol. 2001, 54, 356-361. [CrossRef] [PubMed]

49. Gutmann, I. L-(+)-lactate determination with lactate dehydrogenase and NAD. In Methods of Enzymatic Analysis; Academic Press: Cambridge, MA, USA, 1974; pp. 1464-1468.

50. Nishikimi, M.; Roa, N.; Yogi, K. Measurement of superoxide dismutase. Biochem. Biophys. Res. Commun 1972, 46, 849-854. [CrossRef]

51. Ohkawa, H.; Ohishi, N.; Yagi, K. Assay for lipid peroxides in animal tissues by thiobarbituric acid reaction. Anal. Biochem. 1979, 95, 351-358. [CrossRef]

52. Gl, E. Tissue sulfhydryl groups. Arch. Biochem. Biophys. 1959, 82, 70-77.

53. Boyd, C.; Petersen, S.; Gilbert, W.; Rodgers, R.; Fuhlendorf, S.; Larsen, R.; Wolfe, D.; Jensen, K.; Gonzales, P.; Nenneman, M. Evaluation of Methods Used to Improve Grasslands as Ring-Necked Pheasant (Phasianus colchicus) Brood Habitat; Analytical Software, Statistix 9; ProQuest Dissertations Publishing: Tallahassee, FL, USA, 2018; Volume 72, p. 82.

54. El Sheikha, A.; Zaki, M.; Bakr, A.; El Habashy, M.; Montet, D. Physico-chemical properties and biochemical composition of Physalis (Physalis pubescens L.) fruits. Food 2008, 2, 124-130.

55. El Sheikha, A.F.; Piombo, G.; Goli, T.; Montet, D. Main composition of Physalis (Physalis pubescens L.) fruit juice from Egypt. Fruits 2010, 65, 255-265. [CrossRef]

56. Naeem, M.A.; Hassan, L.K.; El-Aziz, M.A. Enhancing the pro-health and physical properties of ice cream fortified with concentrated golden berry juice. Acta Sci. Pol. Technol. Aliment. 2019, 18, 97-107.

57. Ballesteros-Vivas, D.; Alvarez-Rivera, G.; León, C.; Morantes, S.J.; Ibánez, E.; Parada-Alfonso, F.; Cifuentes, A.; Valdés, A Anti-proliferative bioactivity against HT-29 colon cancer cells of a withanolides-rich extract from golden berry (Physalis peruviana L.) calyx investigated by Foodomics. J. Funct. Foods 2019, 63, 103567. [CrossRef]

58. El-Gengaihi, S.E.; Hassan, E.E.; Hamed, M.A.; Zahran, H.G.; Mohammed, M.A. Chemical composition and biological evaluation of Physalis peruviana root as hepato-renal protective agent. J. Diet. Suppl. 2013, 10, 39-53. [CrossRef] [PubMed]

59. Hsieh, K.-Y.; Tsai, J.-Y.; Lin, Y.-H.; Chang, F.-R.; Wang, H.-C.; Wu, C.-C. Golden berry $4 \beta$-hydroxywithanolide E prevents tumor necrosis factor $\alpha$-induced procoagulant activity with enhanced cytotoxicity against human lung cancer cells. Sci. Rep. 2021, 11, 4610. [CrossRef]

60. Coballase-Urrutia, E.; Pedraza-Chaverri, J.; Cárdenas-Rodríguez, N.; Huerta-Gertrudis, B.; García-Cruz, M.E.; Ramírez-Morales, A.; Sanchez-Gonzalez, D.J.; Martínez-Martínez, C.M.; Camacho-Carranza, R.; Espinosa-Aguirre, J.J. Hepatoprotective effect of acetonic and methanolic extracts of Heterotheca inuloides against CCl4-induced toxicity in rats. Exp. Toxicol. Pathol. 2011, 63, 363-370. [CrossRef]

61. Tatiya, A.U.; Surana, S.J.; Sutar, M.P.; Gamit, N.H. Hepatoprotective effect of poly herbal formulation against various hepatotoxic agents in rats. Pharmacogn. Res. 2012, 4, 50. [CrossRef]

62. Taj, D.; Khan, H.; Sultana, V.; Ara, J.; Ehteshamul-Haque, S. Antihepatotoxic effect of golden berry (Physalis peruviana Linn.) in carbon tetrachloride (CCl4) intoxicated rats. Pak. J. Pharm. Sci. 2014, 27, 491-494.

63. Fields, R.D. NIH policy: Mandate goes too far. Nature 2014, 510, 340. [CrossRef]

64. Clayton, J.A. Studying both sexes: A guiding principle for biomedicine. FASEB J. 2016, 30, 519-524. [CrossRef]

65. Flórez-Vargas, O.; Brass, A.; Karystianis, G.; Bramhall, M.; Stevens, R.; Cruickshank, S.; Nenadic, G. Bias in the reporting of sex and age in biomedical research on mouse models. Elife 2016, 5, e13615. [CrossRef]

66. Yoon, D.Y.; Mansukhani, N.A.; Stubbs, V.C.; Helenowski, I.B.; Woodruff, T.K.; Kibbe, M.R. Sex bias exists in basic science and translational surgical research. Surgery 2014, 156, 508-516. [CrossRef]

67. Prendergast, B.J.; Onishi, K.G.; Zucker, I. Female mice liberated for inclusion in neuroscience and biomedical research. Neurosci. Biobehav. Rev. 2014, 40, 1-5. [CrossRef] [PubMed]

68. Cao, X.; Feng, F.; Liu, X.; Sun, C.; Yang, X.; Fang, Y.; Li, S. Exogenous secretin improves parenteral nutrition-associated liver disease in rats. J. Pediatric Gastroenterol. Nutr. 2020, 70, 430-435. [CrossRef] [PubMed]

69. Delgado, M.G.; Zamora, A.G.; Gonsebatt, M.; Mata, E.M.; Vargas, G.G.; Rincón, E.C.; Morales, R.P. Subacute intoxication with sodium nitrate induces hematological and biochemical alterations and liver injury in male Wistar rats. Ecotoxicol. Environ. Saf. 2018, 166, 48-55. [CrossRef]

70. Gheshlaghi-Ghadim, A.; Mohammadi, V.; Zadeh-Hashem, E. Protective Effects of Quercetin on Clothianidin-Induced Liver Damage in the Rat Model. Evid.-Based Complementary Altern. Med. 2022, 2022, 9399695. [CrossRef]

71. Yadsar, M.; Shahabpour, E.; Moradi Sarabi, M. Effect of Different Doses of Nitrate Supplements on hepatocellular Damage Markers in Male Sprague Dawley Rats Following One Session of Exercise. Yafteh 2021, 23, 119-133.

72. Boll, M.; Lutz, W.; Becker, E.; Stampfl, A. Mechanism of carbon tetrachloride-induced hepatotoxicity. Hepatocellular damage by reactive carbon tetrachloride metabolites. Z. Naturforschung C 2001, 56, 649-659. [CrossRef] 
73. Valko, M.; Leibfritz, D.; Moncol, J.; Cronin, M.T.; Mazur, M.; Telser, J. Free radicals and antioxidants in normal physiological functions and human disease. Int. J. Biochem. Cell Biol. 2007, 39, 44-84. [CrossRef]

74. Tatsimo, S.J.N.; de Dieu Tamokou, J.; Havyarimana, L.; Csupor, D.; Forgo, P.; Hohmann, J.; Kuiate, J.-R.; Tane, P. Antimicrobial and antioxidant activity of kaempferol rhamnoside derivatives from Bryophyllum pinnatum. BMC Res. Notes 2012, 5, 158. [CrossRef]

75. Boots, A.W.; Wilms, L.C.; Swennen, E.L.; Kleinjans, J.C.; Bast, A.; Haenen, G.R. In vitro and ex vivo anti-inflammatory activity of quercetin in healthy volunteers. Nutrition 2008, 24, 703-710. [CrossRef] 